\title{
Erratum to: Benefit distribution mechanism in the team members' scientific research collaboration network
}

\author{
Limei Zhao $\cdot$ Qingpu Zhang $\cdot$ Liang Wang
}

Published online: 6 August 2014

(c) Akadémiai Kiadó, Budapest, Hungary 2014

\section{Erratum to: Scientometrics (2014) 100:363-389 \\ DOI 10.1007/s11192-014-1322-7}

Unfortunately, in the original publication of this article, on page 364, paragraph 1, line 4 the name of the cited author has been misspelled as Wager. The correct name is Wagner and the cited reference is given below:

\section{Reference}

Wagner, C. S. (2008). The new invisible college: Science for development. Washington, DC: Brookings Press.

The online version of the original article can be found under doi:10.1007/s11192-014-1322-7.

L. Zhao $(\bowtie)$

Research Center of Information Resources Management, Heilongjiang University,

Harbin 150080, Heilongjiang, China

e-mail: hdzhaolimei@sina.com

Q. Zhang · L. Wang

HIT-UMKC Institute for Innovation and Entrepreneurship in School of Management, Harbin Institute of Technology, Harbin 150001, Heilongjiang, China 